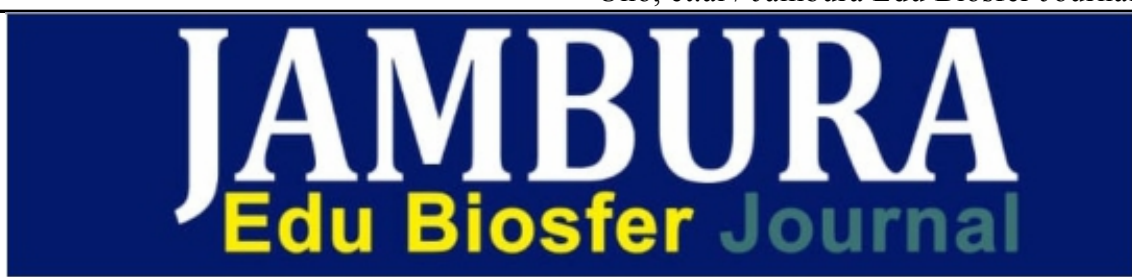

Journal homepage: http://ejurnal.ung.ac.id/index.php/edubiosfer

\title{
VARIASI MORFOMETRIK KEPITING BIOLA (Uca sp.) DI KAWASAN HUTAN MANGROVE CAGAR ALAM TANJUNG PANJANG KECAMATAN RANDANGAN, GORONTALO
}

Ismiyati Uno ${ }^{\mathrm{a}}$, Abubakar Sidik Katili ${ }^{\mathrm{a}}$, Zuliyanto Zakaria ${ }^{\mathrm{a}}$

${ }^{a}$ Program Studi Biologi, Jurusan Biologi, Universitas Negeri Gorontalo, Jl. Jendral Sudirman No.6, Kota Gorontalo 96126 Provinsi Gorontalo, Indonesia Email : dikykatili@gmail.com

\begin{abstract}
The research was aimed at explaining the morphometric ratio of fiddler crab (Uca sp.) based on the difference among the population in Tanjung Panjang Nature Preserve. The technique of data collection was exploration with quantitative descriptive approach. The data analysis test applied average test and T-test. Findings revealed that the variation of the characteristics of morphometric of the two population was different on the characteristics of major claws propondus $(2,55 \pm 0,16 \mathrm{~mm})$ with the highest variation was found in station II $(0,75 \pm 0,09 \mathrm{~mm})$. The morphometric characteristic variations which were significantly different between the two population were carapace, major claws, and mouth. The variations among the population were clearly, seen through carapace posterior width, major claws propondus, major claws dactylus major claws and mouth length.
\end{abstract}

Keywords: Uca sp. crab, Morphometric Variations, Ratio

\section{Pendahuluan}

Kepiting biola merupakan salah satu krustasea yang hidup di habitat pasang surut dan berperan penting di ekosistem mangrove. Nama kepiting biola berasal dari cara makan Uca jantan (Murniati, 2009). Gerakan capit yang terus menerus dari substrat ke mulut dan kembali lagi ke substrat mirip dengan gerakan pemain biola saat menggerakkan busur ke biola (Capit besar) (Rosenberg, 2000).

Kepiting Uca berperan dalam dalam menjaga stabilitas ekosistem mangrove. Kehadiran dan aktivitas kepiting ini mampu mengendalikan jumlah detritus, sumber makanannya antara lain bakteri, protozoa, alga, dan diatom yang ada di ekosistem mangrove (Rosenberg, 2000), selain itu liang tempat tinggalnya mampu membuat sirkulasi udara yang memungkinkan terjadinya perombakan sedimen. Perombakan ini mencegah akumulasi mineral dibagian bawah sedimen, sehingga kandungan unsur hara tetap stabil dan kesuburan untuk pertumbuhan vegetasi tetap terjaga (Pratiwi, 2014).

Jumlah jenis kepiting Uca yang ada di dunia mencapai 97 jenis, sekitar 19 jenis diantaranya ada di Indonesia. Pada genus Uca, yang hidup dalam lingkungan mendukung dapat bertahan hidup hingga mencapai umur 3-4 tahun. Uca yang berusia 12-14 bulan telah dapat melakukan proses perkembangbiakan. Uca memiliki aktivitas kawin yang biasanya terjadi secara serentak. Musim perkembangbiakan kepiting ini biasanya terjadi antara bulan Juni-Agustus. Kondisi siklus kawin kepiting ini tergantung pada kondisi lingkungannya (Wulandari, 2013).

Kelompok genus Uca memiliki karakter yang unik dan mudah dikenali komunitasnya karena terdapat sepasang capit dengan ukuran yang asimetri pada salah satu capit jantan. Menurut Murniati (2012), bahwa asimetri pada capit jantan sudah tampak sejak fase juvenile. Sedangkan pada betina memiliki capit dengan ukuran yang sama. Murniati (2016), dalam setiap jenis kepiting dari populasi yang berbeda memiliki variasi ukuran, morfologi, dan geometri morfometrik. Oleh karena itu diperlukan pengukuran variasi morfometrik pada kepiting Uca. Morfometrik ialah ukuran dalam satuan panjang atau perbandingan ukuran bagian-bagian luar tubuh organisme guna untuk mengetahui pola pertumbuhan, mengukur kematangan gonad, membuktikan jenis-jenis tertentu dalam taksonomi dan mengevaluasi adanya perbedaan populasi (Rachmawati, 2009). 
Kepiting Uca berperan dalam ekologi yang menetap dikawasan mangrove. Salah satu daerah kawasan mangrove yang terdapat beberapa jenis kepiting Uca yang berada di Gorontalo adalah Cagar Alam Tanjung Panjang. Cagar Alam Tanjung Panjang merupakan kawasan konservasi dengan luas wilayah 3000 hektar yang berada di Kabupaten Pohuwato (Bahsoan dkk, 2014). Mangrove di Cagar Alam Tanjung Panjang menyebar di sebagian kecil ruas garis pantai. Saat ini keberadaan mangrove di CATP yang tersisa 600 hektar sebagian besar telah mengalami degradasi akibat alih fungsi lahan menjadi tambak ikan dan udang (Amin dkk, 2018). Dengan adanya degradasi habitat mangrove akan memberikan dampak yang besar bagi biota perairan salah satunya adalah kepiting yang ada dalam ekosistem mangrove tersebut. Menurut Murniati (2016) bahwa, habitat yang telah mengalami perubahan menyebabkan lingkungan dapat memicu kelompok individu dalam ekosistem untuk melakukan adaptasi yang menimbulkan variasi. Berdasarkan hasil observasi morfologi kepiting Uca belum diketahui perbedaan rasio ukuran tubuh dari masing-masing habitat.

Hal yang mendasari perlunya dilakukan penelitian ini adalah untuk menjelaskan variasi morfometrik kepiting $U c a$ sp. berdasarkan antar populasi dari dua habitat mangrove yang berbeda di CATP baik yang sudah mengalami degradasi maupun belum mengalami degradasi.

\section{Metodologi}

\subsection{Tempat dan Waktu Penelitian}

Penelitian ini dilakukan pada dua stasiun di kawasan Cagar Alam Tanjung Panjang Kecamatan Randangan (Gambar 1.). Waktu penelitian dilakukan pada bulan Maret 2019. Pengambilan spesimen pada lokasi yang telah di tentukan dilakukan pada pukul 09.00-13.00 WITA. Spesimen yang ditemukan di lokasi penelitian dibersihkan terlebih dahulu, kemudian difoto dan direndam dengan alkohol 70\% selama \pm 5 menit dan dimasukkan ke dalam botol koleksi yang bersih. Untuk melengkapi data di lapangan diambil data yang berhubungan dengan lingkungan kepiting biola, seperti suhu, $\mathrm{pH}$ dan salinitas.

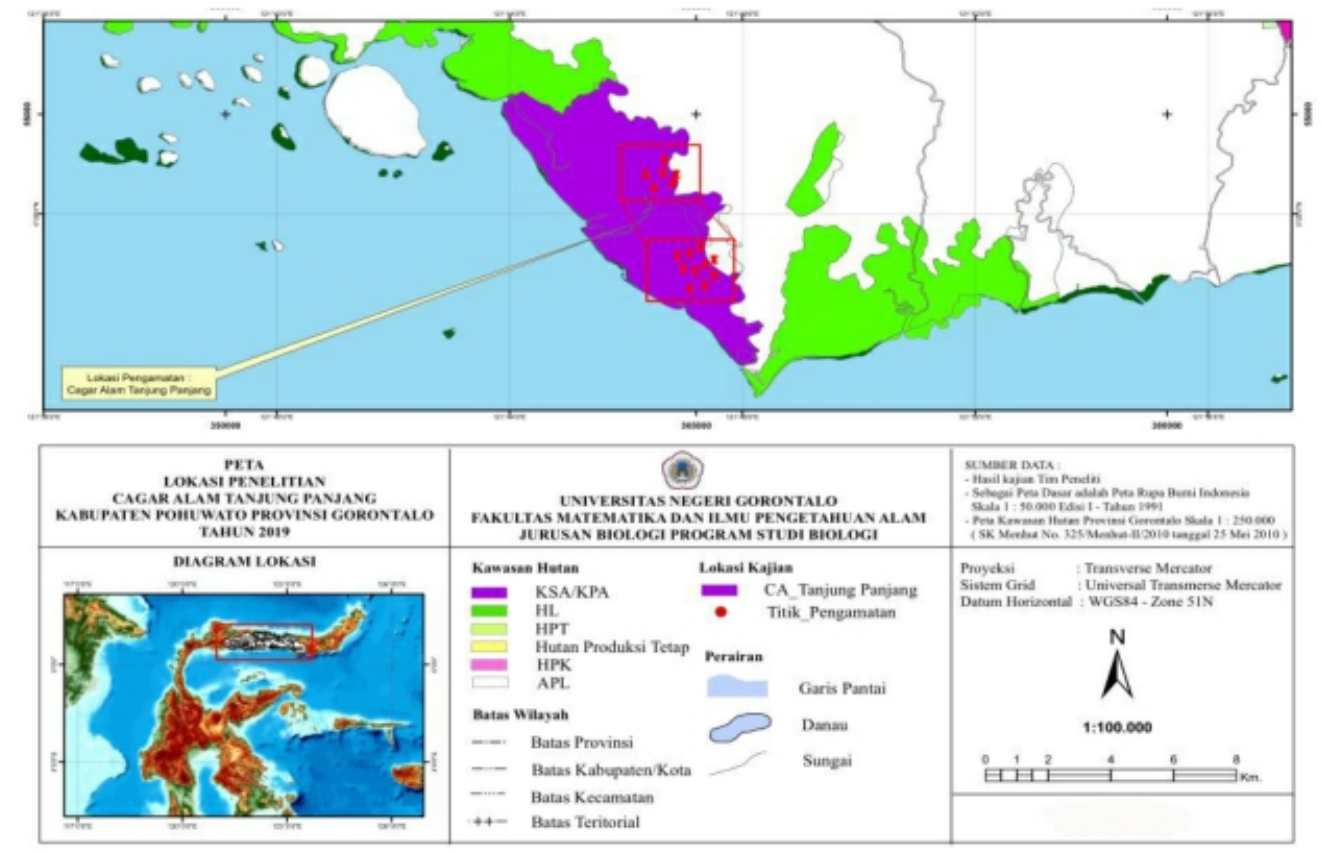

Gambar 1. Peta Penelitian di Dalam Kawasan Cagar Alam Tanjung Panjang, Kabupaten Pohuwato, Provinsi Gorontalo

\subsection{Metode Penelitian dan Teknik Pengambilan Data}

Metode Penelitian dalam penelitian ini menggunakan metode survey dengan pendekatan deskriptif kuantitatif, teknik pengambilan yang digunakan ialah hand sorting/ koleksi langsung.

\subsection{Alat dan Bahan}

Alat yang dilakukan dalam penelitian yaitu kertas lakmus digunakan untuk mengukur $\mathrm{pH}$ air, buku identifikasi menurut Crane 1975, caliper digital untuk mengukur bagian-bagian luar tubuh specimen, kamera untuk dokumentasi penelitian, Global Position System (GPS) sebagai alat penentu lokasi penelitian, Refraktometer untuk mengukur salinitas, botol sampel digunakan sebagai tempat 
wadah, termometer untuk mengukur suhu, sekop kecil untuk menangkap kepiting Uca sp., alat tulis untuk melakukan pencatatan data saat melaksanakan penelitian dilapangan dan kain kasa. Sedangkan bahan yang digunakan adalah alkohol $70 \%$ dan akuades.

\subsection{Pengukuran Parameter Morfometrik}

Bagian - bagian tubuh yang akan diukur ditentukan berdasarkan kunci identifikasi dari Crane (1975). Seperti yang ada pada (Gambar 2).
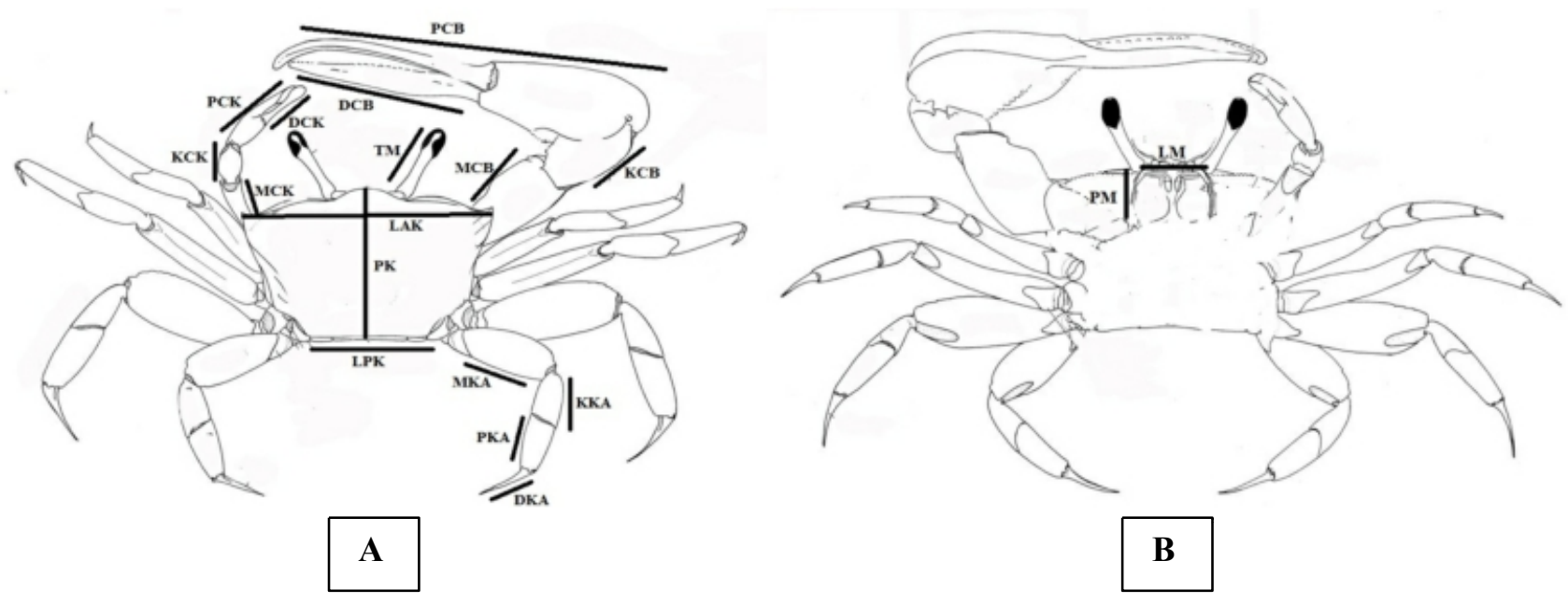

Gambar 2. Morfologi Uca dan karakter yang diukur. (A) Dorsal, (B) Ventral (Murniati, 2016).

Sampel kepiting biola (Uca sp.) yang terkumpul akan diukur secara morfometrik, yang meliputi 18 karakter utama seperti yang dilakukan Murniati (2016) (Tabel 1).

Tabel 1. Karakter Morfometrik Kepiting Uca

\begin{tabular}{|c|c|c|}
\hline No & Karakter Morfometrik & Keterangan \\
\hline 1. & Panjang karapas (PK) & $\begin{array}{l}\text { Jarak antara anterior sampai posterior diukur pada } \\
\text { posisi vertical }\end{array}$ \\
\hline 2. & Lebar anterior karapas (LAK) & $\begin{array}{l}\text { Jarak antara lateral kanan dan lateral kiri, diukur pada } \\
\text { jarak terbesar antara dua sisi karapas bagian anterior }\end{array}$ \\
\hline 3. & Lebar posterior karapas (LPK) & $\begin{array}{l}\text { Jarak antara lateral kanan dan lateral kiri, diukur pada } \\
\text { jarak terkecil antara dua sisi karapas bagian posterior }\end{array}$ \\
\hline 4. & Panjang merus capit kecil (MCK) & $\begin{array}{l}\text { Persendian batas pertama bagian bawah pada capit } \\
\text { kecil sampai batas bagian atas mendekati karpus bagian } \\
\text { bawah. }\end{array}$ \\
\hline 5. & Panjang karpus capit kecil (KCK) & $\begin{array}{l}\text { batas atas merus sampai akhir mendekati propondus } \\
\text { bagian bawah }\end{array}$ \\
\hline 6. & Panjang propodus capit kecil (PCK) & batas atas karpus sampai ujung capit kecil bagian atas \\
\hline 7. & Panjang daktilus capit kecil (DCK) & Batas atas karpus sampai akhir capit kecil bagian bawah \\
\hline 8. & Panjang merus capit besar (MCB) & $\begin{array}{l}\text { Persendian batas pertama mulai dari bagian bawah } \\
\text { mendekati karapas }\end{array}$ \\
\hline 9. & Panjang karpus capit besar (KCB) & $\begin{array}{l}\text { Batas atas merus sampai ujung mendekati propondus } \\
\text { pada capit besar }\end{array}$ \\
\hline 10 . & Panjang propodus capit besar (PCB) & Batas atas karpus sampai ujung capit besar bagian atas \\
\hline 11. & Panjang daktilus capit besar (DCB) & $\begin{array}{l}\text { Batas atas karpus sampai ujung capit besar bagian } \\
\text { bawah }\end{array}$ \\
\hline 12. & Panjang rongga mulut $(\mathrm{PM})$ & Panjang rongga mulut pada ventral \\
\hline 13. & Lebar rongga mulut (LM) & Lebar rongga mulut pada ventral \\
\hline 14. & Panjang merus kaki ke 4 (MKA) & $\begin{array}{l}\text { Batas pertama tepat di persendian kaki ke } 4 \text { mendekati } \\
\text { karpus }\end{array}$ \\
\hline 15 . & Panjang karpus kaki ke 4 (KKA) & Batas atas merus kaki ke 4 sampai batas awal propondus \\
\hline 16. & Panjang propodus kaki ke 4 (PKA) & $\begin{array}{l}\text { Batas atas karpus kaki ke } 4 \text { sampai mendekati batas } \\
\text { bawah daktilus }\end{array}$ \\
\hline 17. & Panjang daktilus kaki ke 4 (DKA) & Batas atas propondus sampai pada ujung kaki \\
\hline
\end{tabular}




\begin{tabular}{lll}
\hline No & Karakter Morfometrik & \multicolumn{1}{c}{ Keterangan } \\
\hline 18. & Panjang tangkai mata (TM) & Diukur pada posisi vertical \\
\hline
\end{tabular}

\subsection{Teknik Analisis Data}

Data yang diperoleh dianalisis untuk melihat variasi morfometrik yang paling berpengaruh yang ada di vegetasi mangrove CATP Kecamatan Randangan. Seluruh data morfometrik mulai dari lebar anterior karapas (LAK) hingga panjang tangkai mata (TM) diperbandingkan dengan panjang karapas (PK).

Contoh:

Rasio = Lebar Anterior Karapas (LAK) / Panjang Karapas (Murniati, 2016).

Data rasio ini digunakan sebagai nilai standar panjang karakter. Murniati (2016), berpendapat bahwa panjang karapas dipilih sebagai pembanding utama. Hal ini bertujuan untuk menghindari pengaruh dimorfisme seksual dalam analisis dan untuk menstandarisasi data, semua karakter yang telah diukur dirasiokan dengan panjang karapas. Ukuran karapas dipilih sebagai pembanding utama karena karakteristik karapas sangat stabil dibandingkan alat gerak (Czerniejewski dkk, 2007). Setelah itu data yang telah dikumpulkan diuji rata-rata tertinggi, standar deviasi, maksimum dan minimum.

Data rasio yang didapatkan dari masing-masing spesies dianalisis secara statistik menggunakan uji $\mathrm{T}$ dengan taraf signifikan 0.05 , namun sebelumnya data rasio yang didapatkan terlebih dahulu diuji normalitas dan homogenitas sebagai uji prasyarat statistik pada taraf signifikan 0.05

\section{Hasil dan Pembahasan}

Kawasan hutan mangrove di Cagar Tanjung Panjang secara administratif sebagian terletak di desa Siduwonge, kecamatan randangan, kabupaten Pohuwato, provinsi Gorontalo. CATP ini merupakan kawasan konservasi yang dikelola oleh Balai Konservasi Sumber Daya Alam Seksi Konservasi Wilayah II Gorontalo dan salah satu kawasan hutan bakau terbesar di Gorontalo seluas $3.174,10$ (tiga ribu seratus tujuh puluh empat dan sepuluh perseratus) hektar di kabupaten Pohuwato (Keputusan Menteri Kehutanan Nomor 325/ Menhut-II 2010).

Penelitian dilakukan di Kawasan mangrove CATP desa Siduwonge, kecamatan Randangan dibagi menjadi dua stasiun pengamatan. Stasiun I terletak pada titik koordinat 0 o 26 ' 52" N 121。47' 12" E tepatnya di dusun Simanagi dan stasiun II terletak pada titik koordinat 0 o 28 ' 45" N 121。46' 45" E tepatnya di dusun Bolongga. Kedua stasiun ini merupakan daerah penyebaran kepiting biola.

Kawasan CATP yang berada di desa Siduwonge pada stasiun pengamatan I (belum terdegradasi) merupakan daerah yang banyak ditumbuhi beberapa jenis mangrove. Jenis mangrove yang menutupi sebagian luas tutupan daerah ini yaitu diantaranya Rhizophora mucronata, Rhizophora apiculata, Avicennia marina, Bruguiera gymnorrhyza, dan yang paling mendominasi yaitu Ceriops tagal. Jenis mangrove ini meliputi tingkat pancang semai dan pohon dan terdapat beberapa jenis mangrove asosiasi lainnya, sedangkan untuk stasiun pengamatan II (sudah terdegradasi) sebagian besar ditumbuhi oleh sedikit mangrove pada tingkat pancang, jenis mangrove ini yaitu Avicennia marina.

\subsection{Hasil Penelitian}

Hasil pengambilan sampel kepiting biola ( $U c a$ sp.) di hutan mangrove CATP, total sampel yang didapatkan yaitu berjumlah 44 individu. Sampel tersebut diambil pada saat air surut yaitu pada pukul 09.00-12.00 WITA dengan kondisi cuaca yang cerah. Hasil penelitian dari dua stasiun tersebut kemudian diidentifikasi dan ditemukan satu jenis yaitu spesies Uca demani jantan dewasa yang diklasifikasikan ke dalam family ocypodidae. Karakteristik dasar dari spesies ini adalah bentuk muka karapas (rostrum) sempit, tangkai mata panjang. Menurut Crane (1975), bahwa muka karapas yang sempit memiliki tangkai mata yang panjang dan begitupun sebaliknya. Selanjutnya area orbit, pada bagian dasar orbit dan suborbit memiliki bintil-bintil. Gonopode adalah alat kopulasi pada jantan (G1) terlihat pada bentuk ujung, posisi ujung saluran terlihat panjang dan ukurannya ramping. Major cheliped (capit besar) yang merupakan karakter kunci dalam identifikasi pada alur poleks dan daktilus ditandai oleh sederetan tubercle (tonjolan kecil) pada permukaan dalam, pada merus (bagian tengah hingga ujung yang biasa disebut jari tidak bergerak) terdapat juga bintil-bintil pada bagian permukaan. Pada capit kecil, ujung jari-jari capit berbentuk sendok dan berfungsi untuk mengangkut substrat pasir dan lumpur. 
Setae pada maksiliped kedua, maksiliped merupakan alat makan yang terdapat pada rongga mulut. Bagian tepi maksiliped ini mempunyai bulu-bulu (setae) plumose setae yang menyerupai bulu pada burung. Warna tubuh Uca demani adalah ungu pucat. Jenis ini ditemukan pada substrat lumpur.

Uca demani mendominasi kawasan konservasi mangrove di CATP, spesies ini ditemukan pada substrat berlumpur dan pada umumnya membuat liang disekitar akar vegetasi mangrove. Uca demani yang merupakan sampel spesimen berasal dari stasiun I sebanyak (22 individu jantan) dan stasiun II sebanyak (22 individu jantan). Ditemukan juga Uca jenis lainnya yaitu Uca dussuimieri, Uca coarctata, namun tidak dapat dikoleksi, karena belum mencapai tahap dewasa.

\subsection{Analisis Deskriptif Morfometrik Uca demani}

Perbedaan jumlah individu ini telah diabaikan karena data telah ditransformasikan dalam bentuk rasio sebelum dianalisis. Sehinga tidak ada penyimpangan data. Berikut ini merupakan hasil pengukuran karakter morfometrik terhadap kepiting Uca demani, untuk lebih jelasnya, karakter morfometrik dari setiap sampel yang diperoleh dapat dilihat pada (Gambar 3 Lampiran 1). Rasio ukuran tubuh pada masing-masing populasi Uca demani tidak selalu tepat sama antar individu dan antar lokasi. Pada grafik menunjukkan terdapat perbedaan rata-rata dan simpangan baku (stdev) antarlokasi.

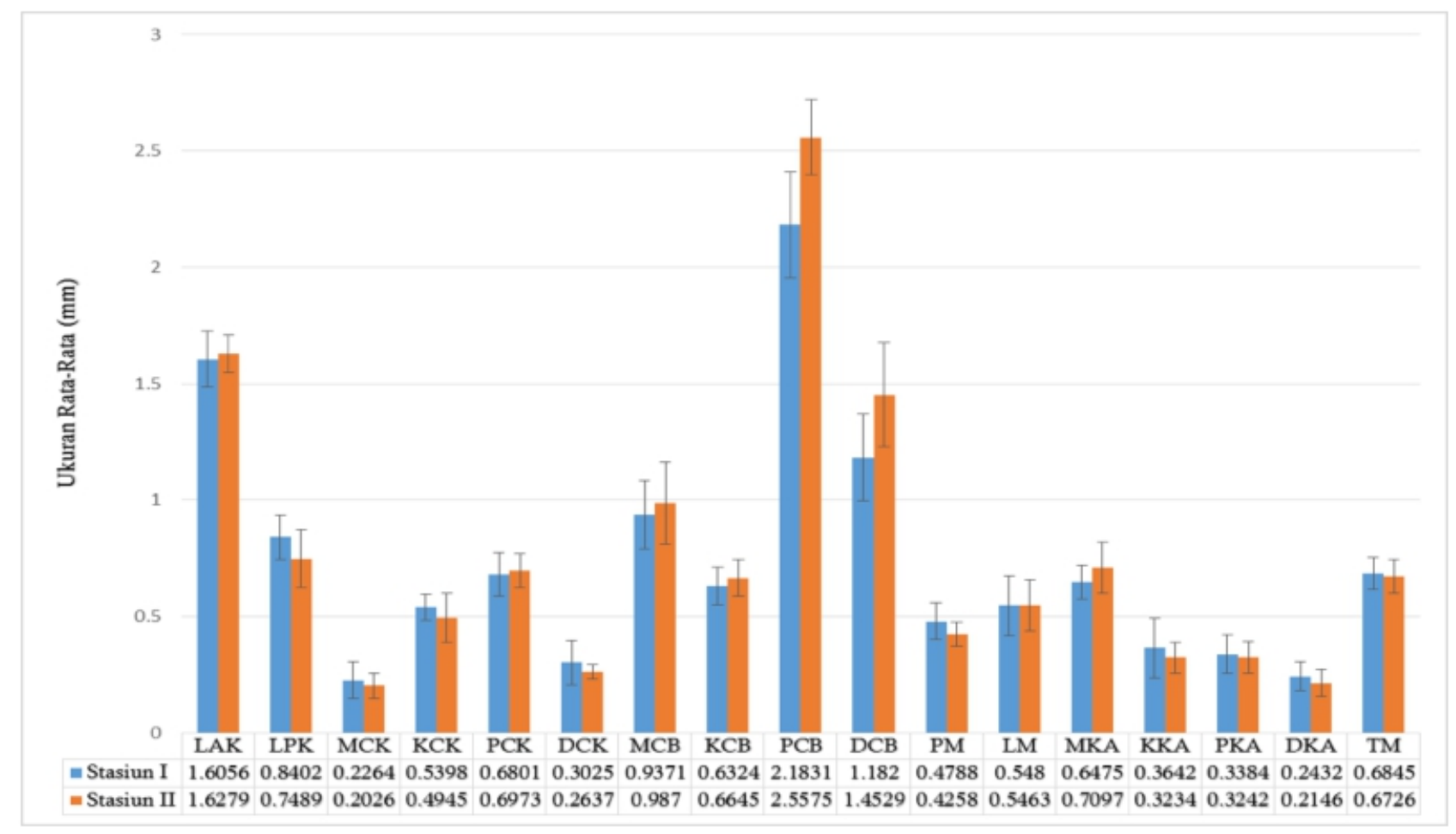

Gambar 3. Rerata Karakter Morfometrik Uca demani. Ket: LAK (lebar anterior karapas), LPK (lebar posterior karapas), MCK (merus capit kecil), KCK (karpus capit kecil), PCK (propondus capit kecil), DCK (daktilus capit kecil), MCB (merus capit besar), KCB( karpus capit besar), PCB (propondus capit besar), DCB (daktilus capit besar), PM (panjang mulut), LM (lebar mulut), MKA (merus kaki ke-4), KKA (karpus kaki ke-4), PKA (propondus kaki ke-4), DKA (daktilus kaki ke-4), TM (tangkai mata).

Hasil yang didapatkan dari gambar diatas merupakan rata-rata dari seluruh karakter morfometrik, rata-rata tertinggi terdapat pada stasiun II $(0,75 \pm 0,09 \mathrm{~mm})$. Hal ini dapat dilihat pada karakter capit besar terutama propondus capit besar (PCB) dengan nilai $(2,55 \pm 0,16 \mathrm{~mm})$.

Karapas: Uca demani memiliki pola warna abu-abu namun sedikit memiliki corak. Bentuk karapas ini terlihat seperti segitiga. Bagian anterior karapas sangat meruncing dan lurus sedangkan untuk posterior karapas terlihat melengkung. Berdasarkan rasio karakter lebar anterior karapas (LAK) pada Uca demani jantan di stasiun I berkisar antara $(1,36-1,95 \mathrm{~mm})$, sedangkan stasiun II berkisar antara $(1,49-1,82 \mathrm{~mm})$. Nilai rata-rata tertinggi dari Uca demani yaitu terdapat pada stasiun II (1,62 $\mathrm{mm})$, sedangkan yang terendah pada stasiun I (1,60 mm). Rasio karakter lebar posterior karapas (LPK) 
pada Uca demani berkisar antara (0,61-1,01 mm). Nilai rata-rata tertinggi terdapat pada stasiun I $(0,84$ $\mathrm{mm})$, sedangkan nilai terendah pada stasiun II $(0,74)$.

Capit Kecil: Pada umumnya Uca jantan memiliki capit kecil menyerupai capit pada Uca betina (Rosenberg, 2001). Pada capit kecil Uca demani memiliki banyak setae pada bagian daktilus dan manus. Crane (1975), mengatakan bahwa morfologi capit kecil berkaitan dengan tipe habitat . Rasio karakter merus capit kecil (MCK) stasiun I berkisar $(0,11-0,40 \mathrm{~mm})$, sedangkan stasiun II $(0,12-0,30 \mathrm{~mm})$. Nilai rata-rata tertinggi terdapat pada stasiun $\mathrm{I}(0,22 \mathrm{~mm})$, sedangkan terendah pada stasiun $(0,20 \mathrm{~mm})$. Rasio karakter karpus capit kecil (KCK) pada stasiun I berkisar antara $(0,45-0,65 \mathrm{~mm})$, sedangkan stasiun II $(0,06-0,57 \mathrm{~mm})$. Nilai rata-rata tertinggi terdapat pada stasiun I $(0,53 \mathrm{~mm})$, sedangkan nilai terendah pada stasiun II $(0,49 \mathrm{~mm})$. Rasio karaker propondus capit kecil (PCK) pada stasiun I berkisar antara $(0,49-0,81 \mathrm{~mm})$, stasiun II $(0,59-0,85 \mathrm{~mm})$. Nilai rata-rata tertinggi terdapat pada stasiun II $(0,69$ $\mathrm{mm})$, sedangkan terendah pada stasiun I $(0,68 \mathrm{~mm})$. Rasio karakter daktilus capit kecil (DCK) pada stasiun I berkisar antara $(0,15-0,51 \mathrm{~mm})$, sedangkan stasiun II yaitu $(0,19-0,33 \mathrm{~mm})$. Nilai rata-rata tertinggi pada stasiun I $(0,30 \mathrm{~mm})$, sedangkan nilai terendah pada stasiun II $(0,26 \mathrm{~mm})$.

Capit Besar: Merus capit besar (MCB), pada bagian merus hanya sedikit terdapat tubercle (tonjolan kecil). Rasio karakter merus pada capit besar (MCB) di stasiun I berkisar antara $(0,72-1,19$ $\mathrm{mm})$, sedangkan stasiun II $(0,70-1,25 \mathrm{~mm})$. Nilai rata-rata tertinggi terdapat pada stasiun II $(0,98 \mathrm{~mm})$, sedangkan nilai terendah pada stasiun I $(0,93 \mathrm{~mm})$. Rasio karakter karpus capit besar (KCB) pada stasiun I memiliki panjang antara $(0,48-0,77 \mathrm{~mm})$, sedangkan stasiun II $(0,48-0,82 \mathrm{~mm})$. Nilai rata-rata tertinggi terdapat pada stasiun II $(0,66 \mathrm{~mm})$, sedangkan terendah pada stasiun I $(0,63 \mathrm{~mm})$. Propondus capit besar (PCB) memiliki banyak tubercle (tonjolan kecil) sampai pada bagian daktilus, sehingga terlihat seperti bergerigi kecil dan teratur. Rasio karakter Untuk stasiun I panjang propondus mencapai $(1,73-2,65 \mathrm{~mm})$ dan stasiun II $(2,11-2,78 \mathrm{~mm})$. Nilai rata-rata tertinggi terdapat pada stasiun II $(2,55$ $\mathrm{mm})$, sedangkan terendah pada stasiun I $(2,18 \mathrm{~mm})$. Rasio karakter daktilus capit besar (DCB) pada stasiun I mencapai $(0,78-1,56 \mathrm{~mm})$ dan stasiun II $(0,99-1,75 \mathrm{~mm})$. Nilai rata-rata tertinggi terdapat pada stasiun II $(1,45 \mathrm{~mm})$, sedangkan terendah pada stasiun I $(1,18 \mathrm{~mm})$.

Mulut: rasio karakter panjang mulut (PM) Uca demani stasiun I $(0,38-0,72 \mathrm{~mm})$ dan stasiun II $(0,31-0,51 \mathrm{~mm})$. Nilai rata-rata tertinggi terdapat pada stasiun I $(0,47 \mathrm{~mm})$ sedangkan terendah terdapat pada stasiun II $(0,42 \mathrm{~mm})$. Rasio karakter lebar mulut (LM) stasiun I berkisar antara $(0,39-1,07 \mathrm{~mm})$ dan stasiun II $(0,45-0,94 \mathrm{~mm})$. Nilai rata-rata untuk karakter lebar mulut memiliki nilai yang sama terhadap dua stasiun yaitu $(0,54 \mathrm{~mm})$.

Kaki: Rasio karakter merus kaki keempat (MKA) didapatkan hasil yaitu pada stasiun I $(0,53-$ $0,86 \mathrm{~mm})$ dan stasiun II $(0,56-0,98 \mathrm{~mm})$. Nilai rata-rata tertinggi terdapat pada stasiun II $(0,02 \mathrm{~mm})$ sedangkan terendah pada stasiun I $(0,64 \mathrm{~mm})$. Rasio karakter anjang karpus kaki keempat (KKA) didapatkan hasil pada stasiun I $(0,18-0,77 \mathrm{~mm})$ dan stasiun II $(0,21-0,44 \mathrm{~mm})$. Nilai rata-rata tertinggi terdapat pada stasiun I $(0,36 \mathrm{~mm})$, sedangkan terendah pada stasiun II $(0,32 \mathrm{~mm})$. Rasio karakter propondus kaki keempat (PKA) untuk stasiun I didapatkan hasil $(0,18-0,45 \mathrm{~mm})$ dan stasiun II $(0,22-$ $0,43 \mathrm{~mm})$. Nilai rata-rata tertinggi terdapat pada stasiu satu $(0,33 \mathrm{~mm})$, sedangkan nilai terendah pada stasiun II (0,32 mm). Rasio karakter daktilus kaki ke empat (DKA) untuk stasiun I (0,13-0,34 mm) dan stasiun II $(0,10-0,31 \mathrm{~mm})$. Nilai rata-rata tertinggi terdapat pada stasiun I $(0,24 \mathrm{~mm})$, sedangkan terendah pada stasiun II $(0,21 \mathrm{~mm})$.

Tangkai Mata: Kepiting Uca pada umumnya memiliki ciri khas yang mudah dikenali dan dibedakan terhadap kepiting lain, yaitu dengan memiliki tangkai mata yang tinggi berdiri tegak dibandingkan dengan kepiting genus lainnya (Rosenberg, 2001). Hasil yang didapatkan terhadap rasio karakter tangkai mata Uca demani pada stasiun I yaitu $(0,56-0,78 \mathrm{~mm})$, sedangkan stasiun II memiliki panjang yang tidak jauh berbeda terhadap stasiun I yaitu $(0,49-0,79 \mathrm{~mm})$. Nilai rata-rata tertinggi terdapat pada stasiun I $(0,68 \mathrm{~mm})$, sedangkan nilai terendah terdapat pada stasiun II $(0,67 \mathrm{~mm})$.

\subsection{Analisis Deskriptif Morfometrik Uca demani}

Hasil pengujian statistik dari data yang diperoleh dengan menggunakan uji prasayarat berupa uji homogenitas dan normalitas (Kolmogrof-Smirnov) menunjukkan bahwa dari ketujuh belas karakter morfometrik yang diuji, hanya lima karakter yang tidak memenuhi uji prasyarat statistik parametrik (nilai signifikan $<$ nilai $\alpha$ ), karakter tersebut meliputi : daktilus capit kecil (DCK), merus kaki keempat (MKA), karpus capit kecil (KCK), merus capit besar (MCB), dan lebar mulut (LM). Selanjutnya pengujian dua belas karakter morfometrik yang memenuhi prasyarat uji parametrik (nilai signifikan $>$ nilai $\alpha$ ) (Lampiran 2), pengujian dilakukan dengan menggunakan analisis uji T. Hasilnya menunjukkan 
bahwa beberapa karakter morfometrik dari sampel yang diperoleh berbeda secara signifikan. Karakter tersebut diantaranya adalah lebar posterior karapas (LPK), panjang capit besar (PCB), daktilus capit besar (DCB), dan panjang mulut (PM). Untuk lebih jelasnya hasil pengujian statistik ditunjukkan (Tabel 2).

\begin{tabular}{lc}
\multicolumn{1}{c}{ Tabel 2. Hasil Analisis Uji T Independent } \\
\cline { 2 - 2 } Karakter Morfometrik & Nilai Sig. (2-tailed) \\
\hline Panjang karpus capit besar (KCB) & 0.189 \\
Lebar anterior karapas (LAK) & 0.472 \\
Lebar posterior karapas (LPK) * & 0.01 \\
Panjang merus capit kecil (MCK) & 0.249 \\
Panjang propodus capit kecil (PCK) & 0.496 \\
Panjang propodus capit besar (PCB) * & 0 \\
Panjang daktilus capit besar (DCB) * & 0 \\
Panjang rongga mulut (PM) * & 0.011 \\
Panjang karpus kaki ke 4 (KKA) & 0.19 \\
Panjang propodus kaki ke 4 (PKA) & 0.538 \\
Panjang daktilus kaki ke 4 (DKA) & 0.125 \\
Panjang tangkai mata (TM) & 0.58 \\
\hline
\end{tabular}

Keteragan : Karakter yang diberi tanda bintang $(*)$ adalah karakter yang menunjukkan perbedaan secara statistik. Karakter tersebut adalah lebar posterior karapas (LPK), propondus capit besar (PCB), daktilus capit besar (DCB), dan panjang mulut (PM).

\subsection{Parameter Lingkungan}

Hasil pengukuran parameter kualitas air pada kedua stasiun yang dilakukan di CA Tanjung Panjang, dapat dilihat pada Gambar 4.

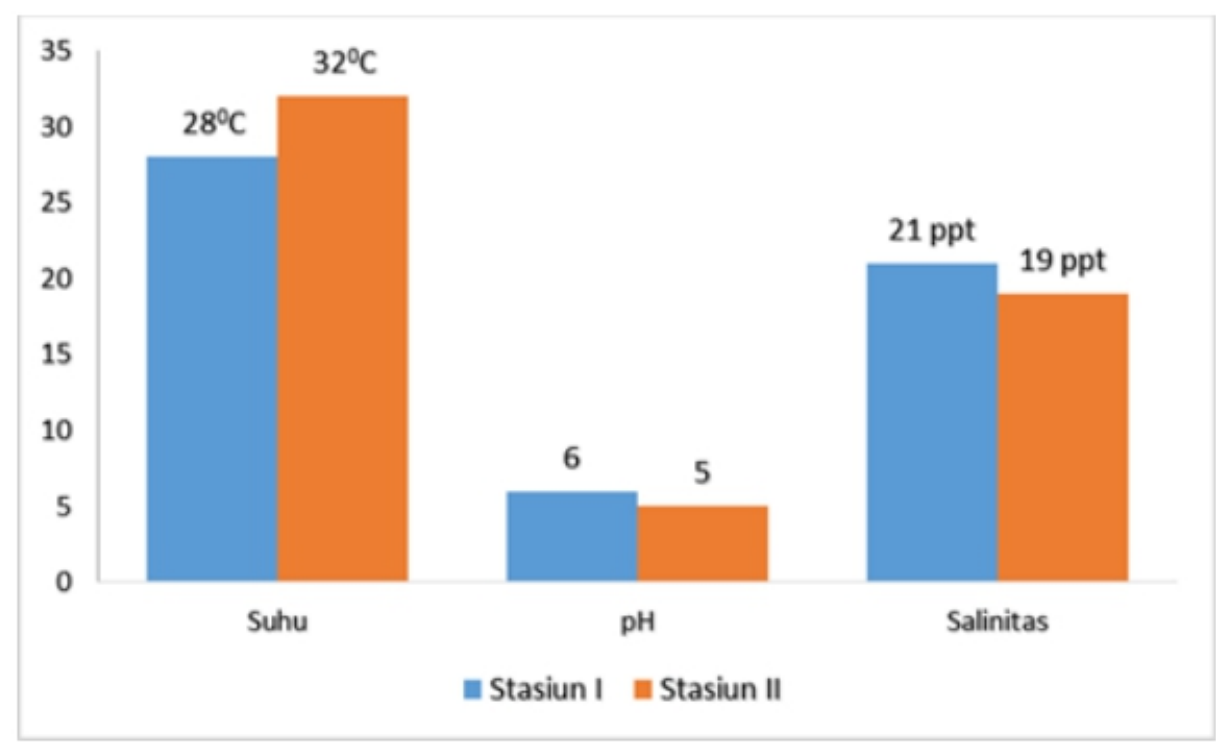

Gambar 4. Parameter Lingkungan

\subsubsection{Suhu}

Suhu perairan merupakan faktor yang amat penting bagi kehidupan organisme diperairan. Suhu juga dapat mempengaruhi terhadap kehidupan dan pertumbuhan bagi biota air. Peningkatan suhu menyebabkan peningkatan dekomposisi bahan organik oleh mikroba (Hamuna dkk, 2018). Hasil pengukuran suhu permukaan air diperoleh pada setiap stasiun memiliki nilai yang agak jauh berbeda seperti yang ditunjukkan pada (Gambar 4). Kisaran yang didapat dari hasil pengukuran yaitu antara 
28-32。C. Hal ini dikarenakan pengamatan dilakukan pada pagi hari hingga siang hari (09.00-12.00) WITA. Kisaran suhu ini masih tergolong baik bagi kepiting Uca. Menurut Budiman dkk (2014), kondisi faktor lingkungan yang masih tergolong baik standar baku mutu ait laut yaitu suhu berkisar antara 28-32。C, sedangkan Suprayogi dkk (2014), mengatakan secara umum kepiting hidup pada vegetasi mangrove, dapat bertahan pada suhu 23-32。C. Hal ini menunjukkan bahwa suhu rata-rata di kawasan mangrove CATP masih dapat menunjang pertumbuhan dan perkembangan kepiting Uca.

\subsection{2 $p H($ Derajat Keasaman)}

Hasil pengukuran $\mathrm{pH}$ dalam penelitian ini adalah berkisar antara 5-6. Kisaran nilai pH ini relatif lebih rendah. Berdasarkan keputusan Menteri Negara Lingkungan Hidup No. 51 Tahun 2004 bahwa standar baku mutu terhadap $\mathrm{pH}$ perairan yaitu 7-8,5. Menurut Suprayogi dkk (2014), menyatakan bahwa $\mathrm{pH}$ yang kurang dari 5 dan lebih dari 9 akan menciptakan suatu kondisi yang tidak menguntungkan bagi kehidupan makrozobentos termasuk krustasea salah satunya yaitu kepiting Uca. Hal ini menunjukkan bahwa kisaran $\mathrm{pH}$ yang didapatkan dari kedua stasiun tersebut masih togolong baik bagi kelangsungan hidup kepiting Uca.

\subsubsection{Salinitas}

Nilai salinitas berkisar antara 19,0-21,0 ppt. kisaran ini masih dapat menunjang pertumbuhan bagi kepiting. Hidayat (2011), menyatakan bahwa kepiting Uca dapat hidup dengan baik pada kisaran salinitas 10-35 ppt. Pada stasiun I dan II memiliki nilai yang tidak jauh berbeda. Hal ini menunjukkan bahwa salinitas di kawasan mangrove CATP masih dapat menunjang pertumbuhan dan kehidupan kepiting Uca.

\subsection{Pembahasan}

Berdasarkan hasil penelitian yang dilakukan di Cagar Alam Tanjung Panjang bahwa didapatkan spesies Uca demani yang tergolong dalam family Ocypodidae dengan total jumlah yaitu 44 individu. Dari hasil perhitungan, nilai rata-rata tertinggi ditemukan pada stasiun II terutama pada karakter propondus capit besar (PCB) dan daktilus capit besar (DCB).

Berdasarkan hasil pengujian sampel dengan analisis uji $\mathrm{T}$ menunjukkan bahwa beberapa karakter morfometrik dari sampel yang diperoleh berbeda secara signifikan. Karakter tersebut diantaranya yaitu: lebar posterior karapas (LPK), panjang capit besar (PCB), daktilus capit besar (DCB), dan panjang mulut (PM). Untuk lebih jelasnya hasil pengujian statistik ditunjukkan pada (Tabel 2).

Karakter lebar posterior karapas (LPK) yang berbeda secara signifikan seperti yang ditunjukkan pada (Tabel 2) dapat diketahui bahwa berdasarkan perbandingan rasio pada kedua populasi tersebut, diduga karena proses ekologi yang saling berinteraksi dalam proses adaptasi seperti kondisi habitat dan makanannya. Hasil parameter lingkungan yang didapatkan berupa suhu, $\mathrm{pH}$, dan salinitas menghasilkan kondisi ideal terdapat pada stasiun I (belum terdegradasi) selain itu karena memiliki sejumlah serasah yang merupakan makanan bagi kepiting yang telah terurai menjadi detritus, hal ini sangat mendukung kelangsungan hidup bagi kepiting. Krisnawati dkk (2018), mengatakan bahwa kondisi lingkungan perairan yang cukup baik misalnya tingginya nilai $\mathrm{pH}$ maupun salinitas akan sangat menentukan dominasi fitoplankton dan beberapa biota lainnya. Hal ini menunjukkan kondisi lingkungan sangat mempengaruhi kehadiran kepiting pada habitat alaminya. Sedangkan pada stasiun II (terdegradasi) merupakan kondisi lingkungan yang kurang baik, karenya sedikitnya nutrisi yang didapatkan. Menurut penelitian Hampton (2014), bahwa kondisi habitat yang baik akan mempengaruhi morfologi karapas bagi kepiting, dalam hal ini kedua wilayah memiliki karakter lingkungan yang berbeda, sehingga organisme yang berada dikedua wilayah ini melakukan adaptasi morfologi. Salah satu hasil adaptasi morfologi adalah ukuran tubuh seperti pada lebar karapas. Ukuran tubuh merupakan hasil adaptasi terhadap keragaman habitat, ketersediaan sumber energi, dan kompetisi.

Selanjutnya karakteristik propondus capit besar (PCB) dan daktilus capit besar (DCB) yang signifikan dlihat pada (Tabel 2) Grafik rerata rasio morfometrik menjelaskan karakter Uca demani pada antar lokasi cenderung seragam, kecuali pada capit besar yang ditemukan pada stasiun II (terdegradasi). Perbedaan sangat terlihat jelas terutama pada propondus dan daktilus capit besar. Berdasarkan karakteristik capit besar, populasi pada stasiun I cenderung lebih kecil variasi ukurannya 
bila dibandingkan populasi pada stasiun II. Hal ini diduga karena ketersediaan makanan dan lubang sarang tempat kepiting ini tinggal, sehingga terdapat pengaruh variasi ukuran antar populasi yang menyebabkan rasio pertumbuhan capit besar bagi masing-masing individu.

Kondisi dalam stasiun I merupakan mangrove yang cukup banyak sehingga berlimpahnya serasah mangrove, menurut penelitian Murniati (2010), bahwa serasah mangrove dimanfaatkan oleh kepiting genus yang berbeda sebagai konsumen pertama (contoh: Ucides cordatus), kemudian sisa pembakaran dari konsumen pertama ini dapat meningkatkan suplai makanan bagi bakteri dan memberi keuntungan lebih bagi kepiting Uca spp. sebagai pemakan detritus. Kepiting Uca mampu mengendalikan jumlah detritus, ketersediaan makanan (detritus) dalam jumlah yang besar menyebabkan jumlah individu meningkat. Sementara kepiting yang mendominasi kawasan stasiun I maupun II yaitu jenis Uca demani. Meningkatnya jumlah individu di stasiun I, menimbulkan adanya persaingan dan pemangsaan dalam memperebutkan lubang sarang sebagai tempat tinggal, sehingga kompetisi meningkat. Meningkatnya kompetisi ini menyebabkan tingginya rasio karakter capit besar terhadap Uca demani. Kondisi stasiun II yang memiliki mangrove yang sangat sedikit sehingga kurang berlimpahnya serasah mangrove, sehingga ketersediaan materi organik sangat kurang. Hal ini diduga pertumbuhan capit besar pada stasiun II karena adanya perebutan nutrisi sehingga terjadi kompetisi dalam memperoleh makanan. Murniati (2012), mengatakan bahwa keragaman habitat yang tinggi akan meningkatkan kompetisi yang menyebabkan keterbatasan sumber energi.

Populasi Uca demani cukup besar dan berdampingan dengan populasi jenis Uca lainnya. Kompetisi umumnya sering terjadi pada antar individu dalam populasi, namun juga terjadi pada jenis Uca lainnya. Menurut Saher dkk (2015), bahwa pertumbuhan capit besar biasanya dipengaruhi oleh sejumlah faktor lingkungan, seperti ketersediaan makanan, salinitas, suhu, $\mathrm{pH}$,dan juga tempat tinggal. Kepiting Uca jantan biasanya menggunakan capit besarnya untuk bertarung. Semakin besar pertumbuhan capit besar semakin kuat kemampuannya dalam bertarung. Murniati (2010), mengatakan bahwa persaingan yang terjadi dalam satu populasi menghasilkan pola dominasi individu jantan yang ditunjukkan dengan ukuran major cheliped (capit besar).

Karakteristik panjang mulut (PM) yang berbeda secara signifikan seperti yang ditunjukkan pada (Tabel 2) hal yang menyebabkan mulut kepiting Uca demani berbeda secara signifikan adalah diduga karena adanya ketersediaan makanan. Kepiting Uca demani memiliki maksiliped yang berfungsi sebagai alat makan. Maksiliped terdiri dari tiga lapisan dari dalam ke luar. Lapisan luar disebut maksiliped ketiga, tengah disebut makilliped kedua, dan bagian dalam adalah maksiliped pertama. Struktur maksiliped ketiga sama kerasnya dengan karapas (Irawan, 2013). Hal ini berkaitan dengan perilaku makan. Bagian maksiliped ini memiliki setae yang befungsi untuk memisahkan makanan dari substrat yang terdapat pada maklilliped kedua. Crane (1975) mengatakan bahwa bagian tepi maksiliped ini mempunyai bulu-bulu (setae) yang disebut plumose setae yang menyerupai bulu pada burung, jenis inilah ditemukan pada substrat lumpur. Hal ini juga menandakan bahwa bagian mulut Uca demani sangat berkaitan erat dengan habitat tempat mereka hidup seperti adanya setae yang menetukan jenis substrat. Kondisi pada daerah yang terderadasi seperti pada stasiun II memiliki sedikit pakan yang tersedia akan mempengaruhi kebiasaan makan bagi kepiting yaitu terjadi perampasan makanan untuk membutuhkan energi yang cukup, karena energi yang berasal dari pakan yang tersedia untuk pertumbuhan menjadi semakin berkurang atau habis. Semakin banyak pakan yang tersedia maka semakin sering terjadi kepiting melakukan aktivitas dalam mendapatkan makanan sehingga mempengaruhi lebar mulut. Sebaliknya semakin sedikit pakan yang tersedia maka semakin berkurang aktivitas dalam mendapatkan makanan.

Tekanan pada lingkungan yang dipandang sebagai faktor pembatas menimbulkan variasi pada lingkungan yang dapat memicu kelompok individu dalam populasi ekosistem untuk melakukan adaptasi yang menimbulkan variasi agar dapat bertahan hidup. Variasi seperti perilaku, fisiologi, morfologi dan anatomi. Menurut Murniati (2016), mengatakan bahwa pada genus $U c a$, variasi yang paling menonjol dan sangat tinggi terutama pada karapas dan capit besar. Variasi ini berupa ukuran, morfologi, dan warna. Variasi ukuran dapat disebabkan karena adanya persaingan dan pemangsaan, variasi morfologi akibat adaptasi fisiologi dan variasi warna merupakan efek adaptasi terhadap iklim dan geografis. 


\section{Kesimpulan}

Berdasarkan hasil penelitian dapat disimpulkan bahwa variasi karakteristik morfometrik pada kedua populasi berbeda yaitu pada karakteristik propondus capit besar (PCB) $(2,55 \pm 0,16 \mathrm{~mm})$ dengan variasi tertinggi ditemukan pada stasiun II $(0,75 \pm 0,09 \mathrm{~mm})$. Variasi karakter morfometrik yang berbeda signifikan antara dua populasi yang diuji berdasarkan hasil statistik ji $\mathrm{T}$ adalah karapas, capit besar, dan mulut. Variasi antar populasi ini terlihat jelas pada lebar posterior karapas (LPK), propondus capit besar (PCB), daktilus capit besar (DCB), dan panjang rongga mulut (PM).

\section{Ucapan Terima Kasih}

Penulis menyampaikan ucapan terima kasih yang sebesar-besarnya kepada BKSDA SKW Sulut Wilayah II atas bantuannya selama eksplorasi di CA Tanjung Panjang.

\section{Referensi}

Amin, B., R. Dako \& C. Paino. 2018. Konflik Ruang Di Tanjung Panjang Dinamika Pengelolaan Ekosistem Mangrove di Provinsi Gorontalo. Gorontalo: Ideals Publishing.

Bahsoan, A., B. Amin, \& IA. Kadir. 2014. Konflik Cagar Alam Tanjung Panjang. Manado: Balai KSDA Sulawesi Utara.

Budiman, CC., PV. Maabuat., ML. Langoy \& DY. Katili. 2014. Keanekaragaman Echinodermata di pantai Basaan Satu Kecamatan Ratatotok Sulawesi Utara. Jurnal Mipa Unsrat Online, 3, 97-101.

Crane, Jocelyn. 1975. Fiddler Crabs of the World Ocypoddae: Genus Uca. In P. U. Press, Fiddler Crabs of the World (pp. 9-725). New York Zoological Society.

Czerniejewski, P., W. Wawryziank., W. Pasewicz \& A. Beldowska. 2007. A Comparative Analysis Of Two Allochthonous Populations Of The Chinese Mitten Crab (Eriocheir Sinensis H. MilneEdwards, 1853) From The Szczecin Lagoon (NW Poland) And San Francisco Bay (US West Coast). Oceanologia, 49, 353-367.

Hampton, KR., MJ. Hopkins., JC. Mcnamara \& CL. Thurman. 2014. Intraspecific Variation In Carapace Morphology Among Fiddler Crabs (Genus Uca) From The Atlantic Coast Of Brazil. 10.3354/Ab00545, 20, 53-67. Doi:10.3354/Ab00545

Hamuna, B., RHR. Tanjung., Suwito, HK. Maury, \& Alianto 2018. Kajian Kualitas Air Laut dan Indeks Pencemaran Berdasarkan Parameter Fisika-Kimia Di Perairan Distrik Depapre, Jayapura. Jurnal Ilmu Lingkungan, 16(ISSN 1829-8907), 35-43.

Hasan, R., Kasmiruddin \& AK. Wardani. 2014. Morfometri dan Alometri Kepiting Biola Uca perplexa Yang Terdapat Pada Vegetasi Mangrove Di Pulau BAAI, Bengkulu. Seminar Nasional XI Pendidikan Biologi FKIP UNS, (pp. 563-567). Bengkulu.

Hidayat, JW. 2011. Metode Pengendalian Wideng (Sesarma spp) Hama Bibit Mangrove melalui Kegiatan Budidaya Kepiting Bakau Scylla spp. Bioma, 13, 25-33.

Irawan, B. 2013. Karsinologi Dengan Penjelasan Deskriptif dan Fungsional. Surabaya: Airlangga University Press.

[Kementrian Lingkungan Hidup \& Kehutanan] Keputusan Menteri Kehutanan Nomor 325/ MenhutII/ 2010 Tanggal 25 Mei 2010 Tentang Penetapan Kawasan Hutan Cagar Alam Tanjung Panjang.

Krisnawati, Y., IW, Arthana \& APWK. Dewi. 2018. Variasi Morfologi dan Kelimpahan Kepiting Uca spp. di Kawasan Mangrove, Tuban-Bali. Journal of Marine and Aquatic Sciences, 4, 236-243.

Lapolo, N., R. Utina \& DWK. Baderan. 2018. Diversity And Density Of Crabs In Degraded Mangrove Area At Tanjung Panjang Nature Reserve In Gorontalo, Indonesia. Biodiversitas, 19, 1154-1159. 
Murniati, DC. 2009. Perbandingan Luas Tutupan Spoon Tiped Setae Maksiliped Kedua Pada Uca spp. (Brachyrura: Ocypodidae). Jurnal Zoo Indonesia, 18, 1-8.

Murniati, DC. 2010. Keanekaragaman Uca spp. Dari Segara-Anakan, Cilacap, Jawa Tengah Sebagai Pemakan Deposit. Jurnal Fauna Indonesia, 9, 19-23.

Murniati, DC. 2010. Pola Dominasi Capit Pada Uca spp. (Decapoda: Ocypodidae). Pusat Penelitian Biologi-LIPI, 16, 15-20.

Murniati, DC. 2012. Penggunaan Karakter Kuantitatif Dalam Kajian Sistematik Uca (Austruca) (Bott 1973) (Brachyura: Ocypodidae) Di Indonesia. Tesis.

Murniati, DC. 2016. Analisis Morfologi Antar Populasi Uca vocans (Brachyura: Ocypodidae) Pada Beberapa Kawasan Mangrove di Pulau Lombok. Jurnal Zoo Indonesia, 24, 109-120.

Pratiwi, R. 2014. Karakteristik Morfologi Kepiting Mangrove Uca spp. (Crustacea: Decapoda: Ocypodidae). Jurnal Oseana, XXXIX, 23-32.

Rachmawati, PF. 2009. Analisa Variasi Karakter Morfometrik Dan Merisitik Kepiting Bakau (Scylla spp.) Di Perairan Indonesia. Skripsi.

Rosenberg, MS. 2000. The Comparative Claw Morphology, Phylogeny, And B Ehavior Of F Iddler Crabs (Genus Uca). A Dissertation Presented, 1-173.

Rosenberg, MS. 2001. The Systematics And Taxonomy Of Fiddler Crabs: Aphylogeny Of The Genus Uca. Journal Of Crustacean Biology, 21, 839-869.

Saher, NU., NA. Qureshi \& O Sahir. 2015. Distribution, Abundance And Morphometric Analysis Of Uca Sindensis (Family: Ocypodidae) From Korangi Creek Mangrove Area Along Karachi Coast Of Pakistan. Indian Journal Of Geo - Marine Sciences, 44.

Suprayogi, D., J. Siburian, \& A. Hamidah. 2014. Keanekaragaman Kepiting Biola (Uca spp.) Di Desa Tungkai I Tanjung Jabung Barat. Biospecies, 7, 22-28.

Wulandari, T., A. Hamidah, \& J Siburian. 2013. Morfologi Kepiting Biola (Uca spp.) di Desa Tungkal I Tanjung Jabung Barat Jambi. Jurnal Biospecies, 6, 6-14. 